\title{
Fabrication of Sm-Based Perovskite-Type Oxide Thin-Films and Gas Sensing Properties to Acetylene
}

\author{
Tomohisa Tasaki, Satoko Takase, Youichi Shimizu* \\ Department of Applied Chemistry, Kyushu Institute of Technology, Tobata, Japan \\ Email: ${ }^{2}$ shims@tobata.isc.kyutech.ac.jp
}

Received December 7, 2011; revised January 2, 2012; accepted January 10, 2012

\begin{abstract}
Sm-based perovskite-type oxide $\left(\mathrm{SmMeO}_{3}: \mathrm{Me}=\mathrm{Cr}, \mathrm{Mn}, \mathrm{Fe}, \mathrm{Co}\right)$ thin-films could be synthesized by a wet-chemical method using an acetylacetone-Poly(Vinyl Pyrrolidone) (PVP) polymeric precursor method at $750^{\circ} \mathrm{C}$. The perovskitetype oxide thin-films were tried to apply an acetylene gas sensor based on AC impedance spectroscopy. Among the oxides tested, $\mathrm{SmFeO}_{3}$ thin-film sensor showed good sensor responses in which the AC impedance at $20 \mathrm{kHz}$ was depending on acetylene gas concentration between $2 \mathrm{ppm}$ and $80 \mathrm{ppm}$ at $400^{\circ} \mathrm{C}$.
\end{abstract}

Keywords: Perovskite-Type Oxide; Thin-Film; Ac Impedance; Acetylene; Gas Sensor

\section{Introduction}

Lanthanoid-based perovskite-type oxides, such as $\mathrm{LnMeO}_{3}$ (Ln: lanthanoids, Me: transition metals), have been well-known as functional inorganic materials having a wide range of applications for electrode materials of the alkaline fuel cell [1], gas sensor [2-10], ion sensor [11], and for high-performance catalysts for the complete oxidation of hydrocarbons or $\mathrm{CO}$, and $\mathrm{NO}$ reduction [12]. Among the lanthanoid-transition metal perovskite-type oxides, Sm-based oxides seem to be interesting materials as they have the largest amount of adsorbed oxygen [13]. For example, the Sm-based perovskite-type oxide sensors have been reported to detect $\mathrm{NO}_{x}$ [14], volatile organic compounds [15], ethanol [16] and so on. It is also wellknown that the oxide thin-film devices have good properties as electrochemical devices. So far, oxide thin-film with a perovskite-type structure have been prepared by dry processes such as sputtering and electron-beam deposition methods $[17,18]$, as well as the wet processes of the sol-gel method mainly starting from metal alkoxides or organic acid salts $[19,20]$. They can field high-quality oxide thin-films; however, they still have some problems, such as relatively low cost performance and lack of handling of the chemicals using the sol-gel method. Consequently, in this work it is focused attention on a wet process to evade such problem, and perovskite-type oxide could be synthesized by a polymer precursor with metal nitrates contained constituent elements [21,22]. By the way, acetylene $\left(\mathrm{C}_{2} \mathrm{H}_{2}\right)$ is widely used as the fuel for cutting and welding metals, so there are also strong needs

${ }^{*}$ Corresponding author. to detect acetylene as combustible gas. Recently, it has known that small amount of acetylene is to be generated from depleted insulating oils of an oil-immersed transformer. Thus, the acetylene gas sensor could be applicable as a new type of maintenance's marker of the transformers, especially for the large sized transformers set in remote areas.

The conventional chromatographic method for acetylene detection has high accuracy and is widely used, but it is not suitable for on-site monitoring because of the limited portability as well as the high operating cost. So far, considerable efforts have been directed to develop high performance gas sensors for monitoring acetylene, such as electrochemical sensors [23], and semiconductor type sensors [24,25], however, the sensor for detection acetylene have been seldom reported.

In this study, the Sm-based perovskite-type oxide thinfilm as the material of an acetylene sensor was picked up and systematically evaluated about wet-chemical synthesize of perovskite-type oxide thin-film [26] and the $\mathrm{C}_{2} \mathrm{H}_{2}$ sensing properties of the prepared oxide thin-film.

\section{Experimental}

\subsection{Synthesis of Perovskite-Type Oxide Thin-Films}

Perovskite-type oxide $\left(\mathrm{SmMeO}_{3}: \mathrm{Me}=\mathrm{Cr}, \mathrm{Mn}, \mathrm{Fe}, \mathrm{Co}\right)$ thin-films were synthesized by a polymer precursor method [26] as shown in Figure 1. Metal nitrates were dissolved in Ethylene Glycol (EG) solvent with Polyvinylpyrrolidone (PVP) (3.75 wt\%) and acetylacetone (AcAc), as a polymer additive and a coordination agent, 


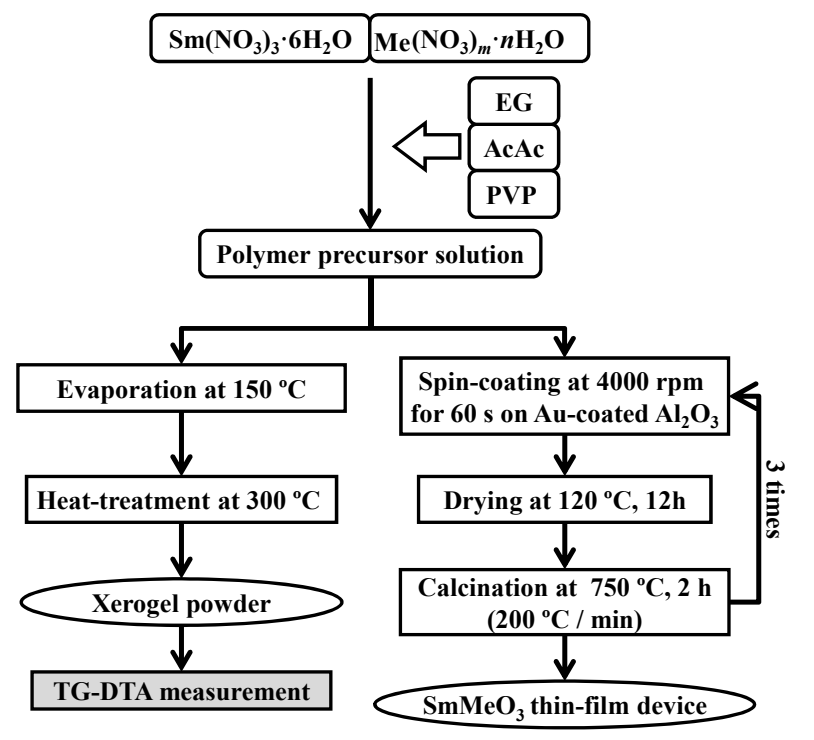

Figure 1. Experimental procedure for preparation of perovskitetype oxide $\mathrm{SmMeO}_{3}(\mathrm{Me}=\mathrm{Cr}, \mathrm{Mn}, \mathrm{Fe}, \mathrm{Co})$ thin-films and Sm-Co xerogel powder.

respectively. The solution thus prepared was spin-coated on an alumina substrate with $\mathrm{Au}$ interdigitated electrodes at $4000 \mathrm{rpm}$, and finally sintered at $750^{\circ} \mathrm{C}$ in air. The spin-coating and sintering processes were repeated several times to adjust the thickness.

The samples were analyzed by X-ray diffraction using $\mathrm{Cu} K \alpha$ radiation (XRD: JEOL JDX3500K), field emission type scanning electron microscope (FE-SEM: JEOL JSM$6500 \mathrm{~F} / \mathrm{III})$, and thermo gravimetric-differential thermal analysis (TG-DTA: Rigaku 8120H). Electrical conductivities of the thin-films were measured in air $\left(\mathrm{PO}_{2}=0.21\right.$ atm) at the temperature range between $200^{\circ} \mathrm{C}$ and $500^{\circ} \mathrm{C}$ in the frequency range from $50 \mathrm{~Hz}$ to $5 \mathrm{MHz}$ with applied voltage of $0.5 \mathrm{~V}$ by AC impedance method (LCR meter: HIOKI 3532-50).

\subsection{Fabrication of Sensor Devices}

Figure 2 shows schematic diagram of the measurement apparatus. The perovskite-type oxide thin-film sensor device was connected to LCR meter with Au lead wires attached with a silver paste covered with an inorganic adhesive. Gas sensing properties were investigated by $\mathrm{AC}$ impedance method using the LCR meter at $400^{\circ} \mathrm{C}$ $500^{\circ} \mathrm{C}$. Sample gases, containing $\mathrm{C}_{2} \mathrm{H}_{2}$ were prepared from a parent gas, i.e., 2 - 80 ppm $\mathrm{C}_{2} \mathrm{H}_{2}$ diluted with nitrogen, by mixing with nitrogen and/or oxygen, were flowed at a total flow rate of $100 \mathrm{~cm}^{3} / \mathrm{min}$. The oxygen partial pressure of the sample gases was fixed at $0.21 \mathrm{~atm}$. Sensitivities of the responses of the sensors were defined as Equation (1);

$$
S_{R, C}[\%]=\frac{R, C_{\mathrm{gas}}-R, C_{\mathrm{air}}}{R, C_{\mathrm{air}}} \times 100
$$

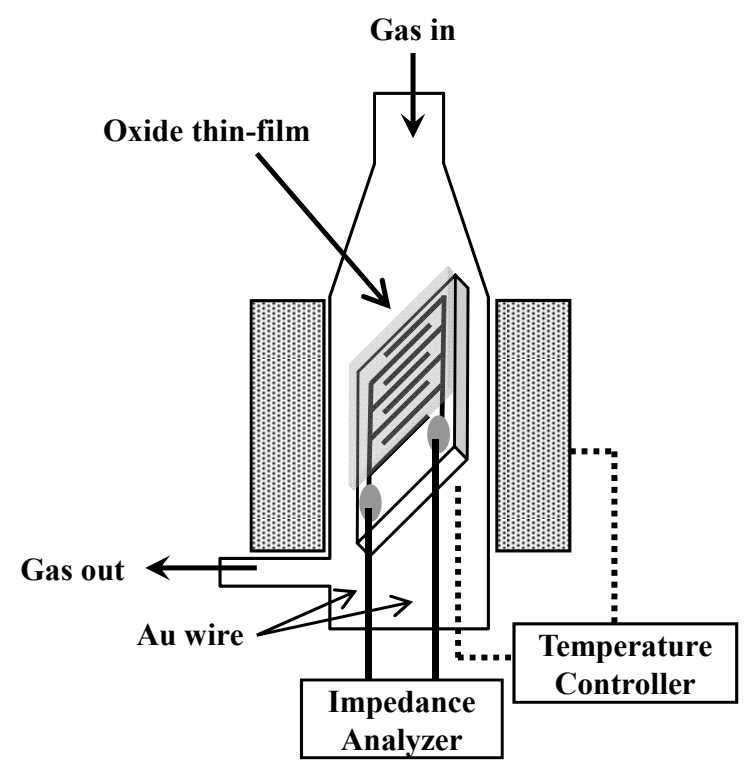

Figure 2. Schematic diagrams of the measurement apparatus and the oxide thin-film device.

where $R_{\text {gas }}\left(C_{\text {gas }}\right)$ and $R_{\text {air }}\left(C_{\text {air }}\right)$ denote Resistance ( $\mathrm{Ca}$ pacitance) in gas and Resistance (Capacitance) in air, respectively.

\section{Results and Discussion}

\subsection{Preparation of Perovskite-Type Oxide Thin-Films}

To determine the thermal heat-treatment temperature, TG-DTA curves of the precursor powder were investigated. As shown in Figure 3, the both curves indicated a weight loss (ca. $5 \%$ ) between room temperature and $200^{\circ} \mathrm{C}$, which corresponds to the thermal decomposition of adsorbed moisture and remained solvent EG in the xerogelpowder. And then, small and large exothermic peaks at around $200^{\circ} \mathrm{C}$ and $300^{\circ} \mathrm{C}$ with both mass decreases were observed. The former seems to correspond to the combustion of AcAc which is not able to connect the network with metal ion, EG and PVP like a polymer and the later corresponds the combustion of the network consisted of them, respectively. The reason why the two mass decreases with exothermic were almost the same might be come from the same amount of the AcAc with or without the polymer connect. An exothermic peak at $650^{\circ} \mathrm{C}$ with mass decrease was probably due to the oxidation and desorption of the remained carbon oxide and crystallization. As stabilization of TG-DTA curves after $700^{\circ} \mathrm{C}$ was observed, the sintering temperature was fixed at $750^{\circ} \mathrm{C}$.

Figure 4 shows XRD patterns of the $\mathrm{SmMeO}_{3}(\mathrm{Me}=$ $\mathrm{Cr}, \mathrm{Mn}, \mathrm{Fe}, \mathrm{Co}$ ) thin-films prepared at $750^{\circ} \mathrm{C}$ by the polymer precursor method on an $\mathrm{Al}_{2} \mathrm{O}_{3}$ substrate with $\mathrm{Au}$ electrode. XRD patterns of the thin-films consisted of perovskite-type oxide phase, $\mathrm{Al}_{2} \mathrm{O}_{3}$ and $\mathrm{Au}$ peaks from 
REVISED

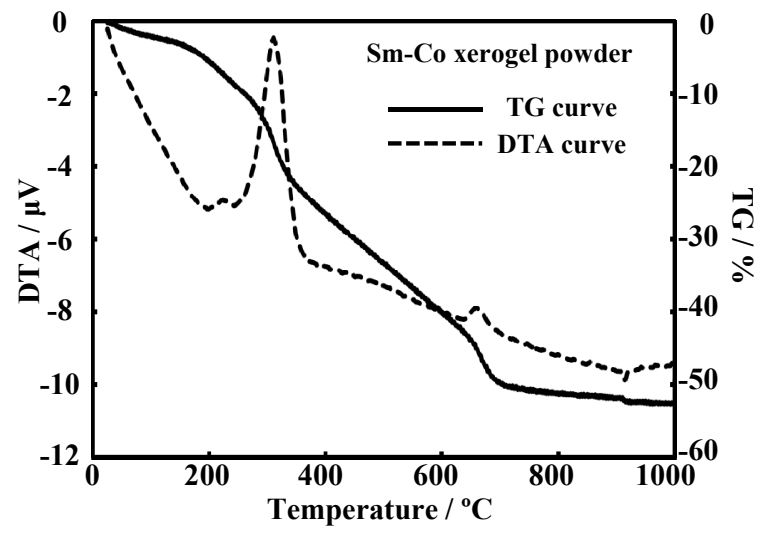

Figure 3. TG-DTA curves of the $\mathrm{Sm}-\mathrm{Co}$ xerogel powder in air until $1000^{\circ} \mathrm{C}\left(10^{\circ} \mathrm{C} / \mathrm{min}\right)$.

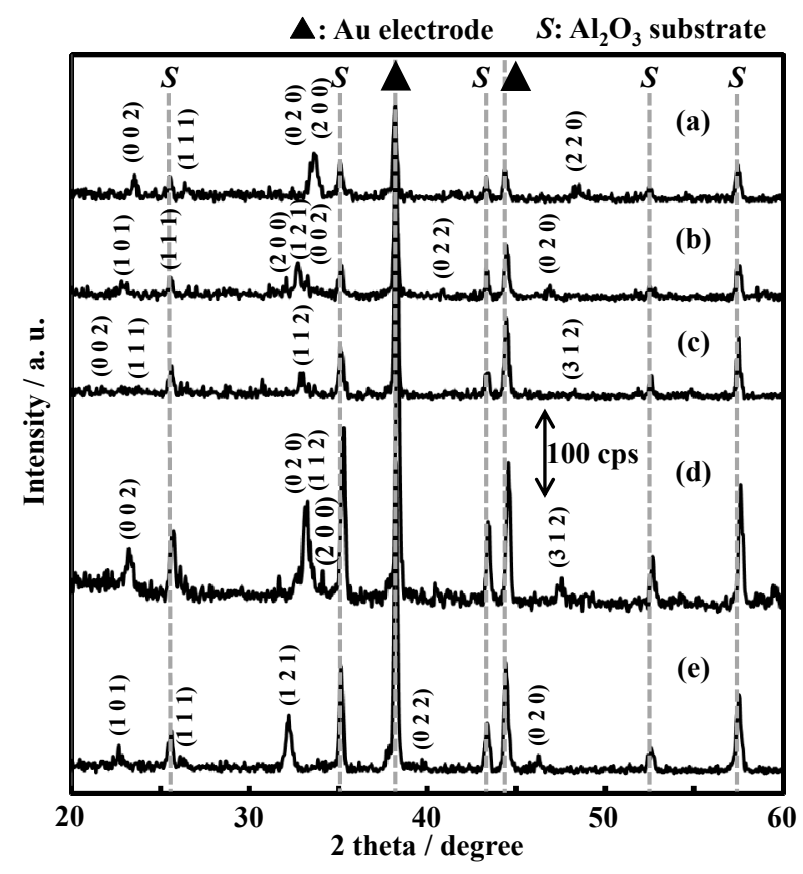

Figure 4. XRD patterns of the perovskite-type oxide Sm$\mathrm{MeO}_{3}(\mathrm{Me}=\mathrm{Cr}, \mathrm{Mn}, \mathrm{Fe}, \mathrm{Co})$ and $\mathrm{LaFeO}_{3}$ thin-films. (a) $\mathrm{SmCoO}_{3}$ (25-1071); (b) $\mathrm{SmFeO}_{3}$ (39-1490); (c) $\mathrm{SmMnO}_{3}$ (250747); (d) $\mathrm{SmCrO}_{3}$ (08-0169); (e) $\mathrm{LaFeO}_{3}$ (37-1493).

the substrate.

SEM images of the $\mathrm{SmMeO}_{3}(\mathrm{Me}=\mathrm{Cr}, \mathrm{Mn}, \mathrm{Fe}, \mathrm{Co})$ thin-films with 3 times spin-coatings were shown in Figure 5. The surface of the $\mathrm{SmFeO}_{3}$ thin-film prepared at $750^{\circ} \mathrm{C}$ was relatively smooth and consisted of homogeneous fine grains of dimension approximately $30 \mathrm{~nm}$, and thickness of the film was ca. $220 \mathrm{~nm}$. The $\mathrm{SmMnO}_{3}$ and $\mathrm{SmCoO}_{3}$ thin-films showed similar characteristics, although the grain size was as large as $50-100 \mathrm{~nm}$. The $\mathrm{SmCrO}_{3}$ thin-film however showed more large grain-size and thickness of the film was ca. $440 \mathrm{~nm}$.

\subsection{Gas Sensing Properties}

For investigate the impedance responses of the sensor devices, the dependence of frequency response on $\mathrm{C}_{2} \mathrm{H}_{2}$ concentration in air $\left(\mathrm{PO}_{2}=0.21 \mathrm{~atm}\right)$ of the sensor devices were firstly measured from $50 \mathrm{~Hz}$ to $5 \mathrm{MHz}$ at the temperature range between $400^{\circ} \mathrm{C}$ and $500^{\circ} \mathrm{C}$. Figure 6 shows Nyquist's plots of the $\mathrm{SmFeO}_{3}$ thin-film device in air and $80 \mathrm{ppm} \mathrm{C}_{2} \mathrm{H}_{2}$ at $400^{\circ} \mathrm{C}$. Although the few disarray plots at lower frequency were observed, the Nyquist's plots showed good-looking semicircles. The increase in resistance change with increasing $\mathrm{C}_{2} \mathrm{H}_{2}$ concentration was observed especially at around $20 \mathrm{kHz}$ which seems to be come from the grain boundary characteristics as shown by equivalent circuits. Moreover, the frequency responses from boundaries between intraparticle and grain boundary were lower by frequency-shifted with

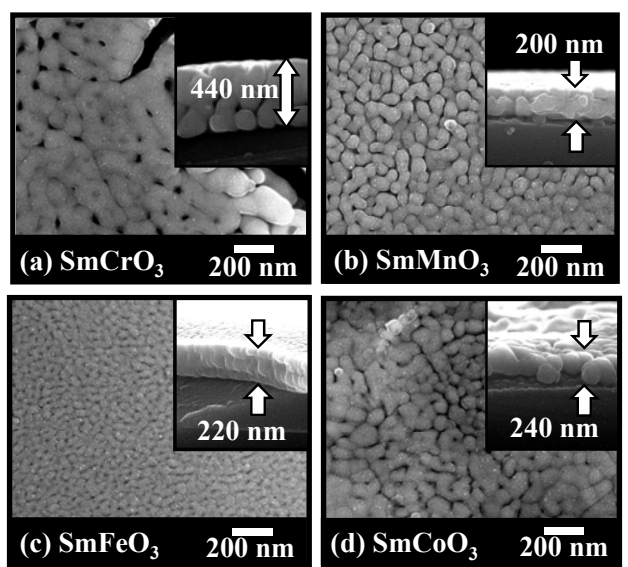

Figure 5. SEM images of the perovskite oxide thin-films on an $\mathrm{Al}_{2} \mathrm{O}_{3}$ substrate with 3 times spin-coatings; (a) $\mathrm{SmCrO}_{3}$; (b) $\mathrm{SmMnO}_{3}$; (c) $\mathrm{SmFeO}_{3}$; (d) $\mathrm{SmCoO}_{3}$.

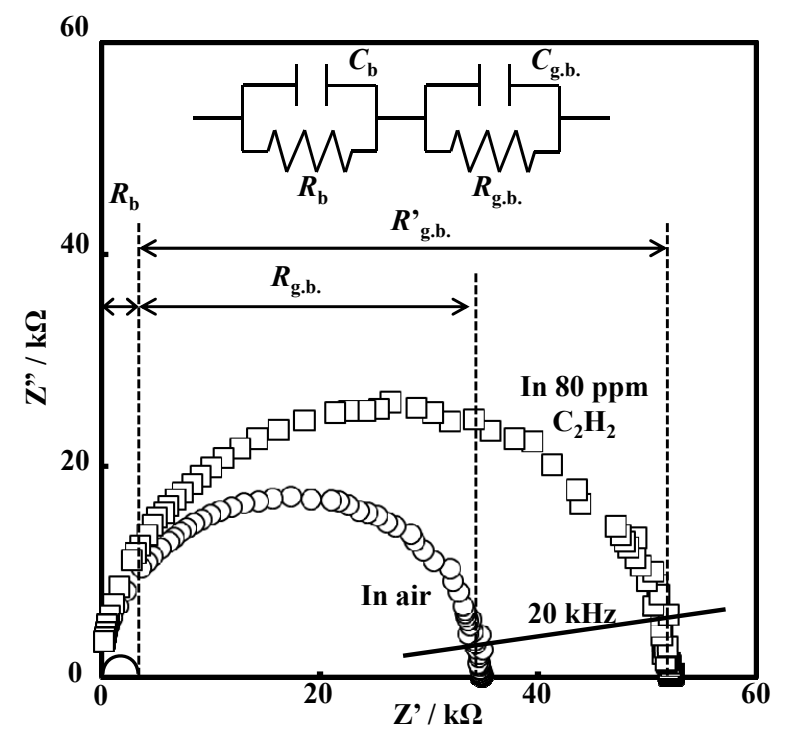

Figure 6. Nyquist's plots and the equivalent circuits for the $\mathrm{SmFeO}_{3}$ thin-film device in air and $80 \mathrm{ppm}$ at $400^{\circ} \mathrm{C}$. 
increasing $\mathrm{C}_{2} \mathrm{H}_{2}$ concentration. Response characteristics of the $\mathrm{SmFeO}_{3}$ and $\mathrm{SmCoO}_{3}$ thin-film devices to $\mathrm{C}_{2} \mathrm{H}_{2}$ at $20 \mathrm{kHz}, 400^{\circ} \mathrm{C}$ are shown in Figures 7 and 8, respectively. The resistance and the capacitance components were divided from the complex impedancemetric measurement. The capacitance responses of both devices showed no response. Although the $\mathrm{SmCoO}_{3}$ thin-film device showed no resistance response at all, it was found that $\mathrm{SmFeO}_{3}$ thin-film device showed excellent resistance sensor response with good response and recovery

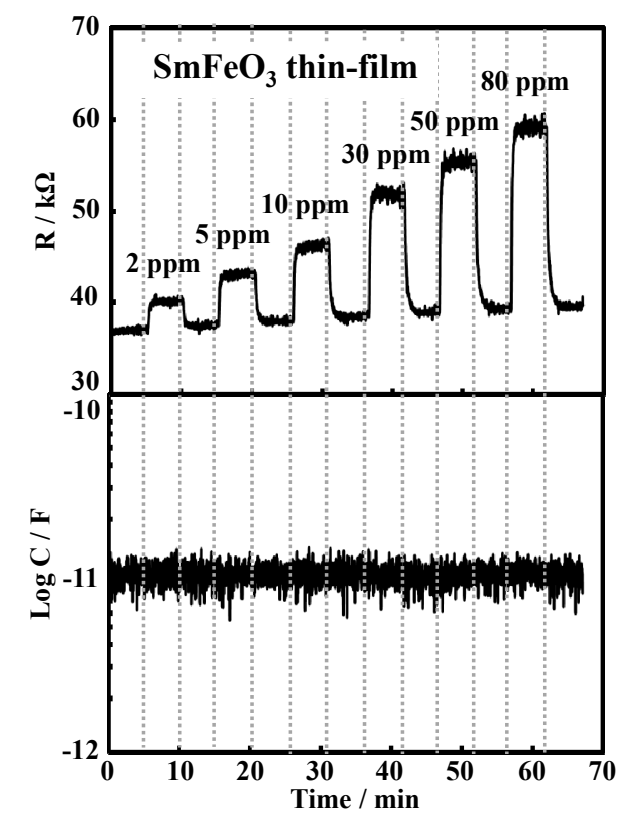

Figure 7. Response transients of $\mathrm{SmFeO}_{3}$ thin-film device to various $\mathrm{C}_{2} \mathrm{H}_{2}$ concentrations at $20 \mathrm{kHz}, 400^{\circ} \mathrm{C}$.

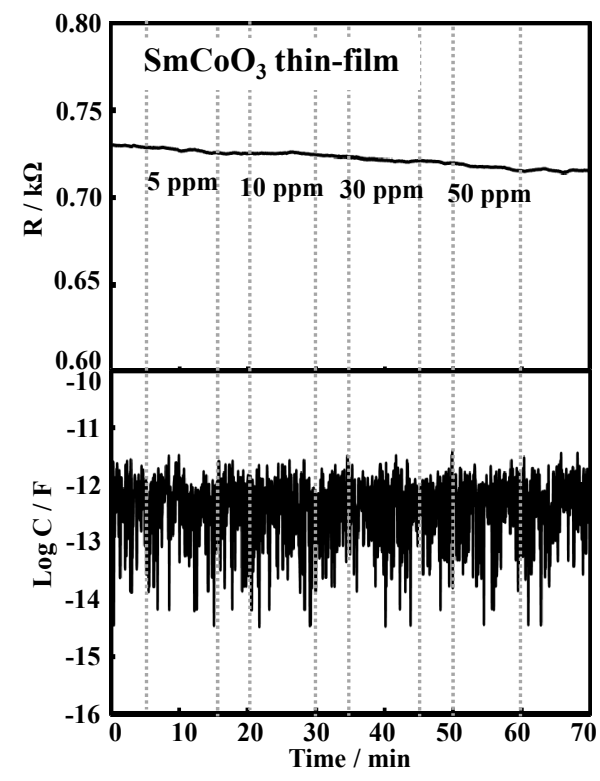

Figure 8. Response transients of $\mathrm{SmCoO}_{3}$ thin-film device to various $\mathrm{C}_{2} \mathrm{H}_{2}$ concentrations at $20 \mathrm{kHz}, 400^{\circ} \mathrm{C}$. rates. As the Fe-doped perovskite-type oxide thin-film device showed the resistance response, the surface adsorption and/or reaction of $\mathrm{C}_{2} \mathrm{H}_{2}$ on the oxide seems to be unique and important. $\mathrm{C}_{2} \mathrm{H}_{2}$ adsorption on oxides should cause the change-transfer in the oxides, which affect the change in resistance as well as capacitance of the oxides. Little capacitance change of the sensor device might be come from the sensor structure, such as the thickness of the oxide and the physical structure of the $\mathrm{Au}$-electrodes. The resistance responses of the $\mathrm{SmFeO}_{3}$ device to various concentration of $\mathrm{C}_{2} \mathrm{H}_{2}$ at $400^{\circ} \mathrm{C}-500^{\circ} \mathrm{C}$ were shown in Figure 9. The responses of $\mathrm{SmFeO}_{3}$ device was decreased with increasing operating temperature from $400^{\circ} \mathrm{C}$ to $500^{\circ} \mathrm{C}$. This seems come from the p-type semi-conductive property and the coverage of oxygen ions of the perovskite-type oxides, because the adsorbed oxygen ions are reduced by reduction reaction on the surface with causing the release of electrons in the perovskites [27-29]. Table 1 summaries the sensitivities of the $\mathrm{SmMeO}_{3}(\mathrm{Me}=\mathrm{Cr}, \mathrm{Mn}, \mathrm{Fe}, \mathrm{Co})$ thin-film devices to $10 \mathrm{ppm} \mathrm{C}_{2} \mathrm{H}_{2}$ at $400^{\circ} \mathrm{C}-500^{\circ} \mathrm{C}$. Unlike the response of the $\mathrm{SmFeO}_{3}$ device, the $\mathrm{SmCoO}_{3}, \mathrm{SmCrO}_{3}$ and $\mathrm{SmMnO}_{3}$

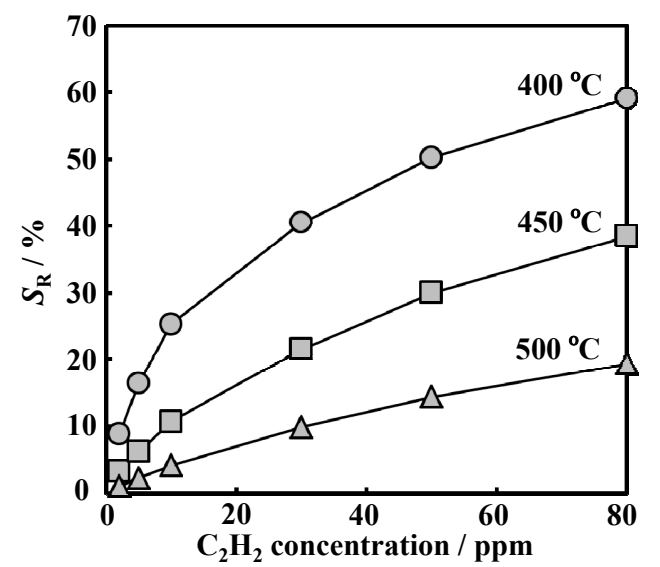

Figure 9. Dependence on $\mathrm{C}_{2} \mathrm{H}_{2}$ concentrations of the Sm$\mathrm{FeO}_{3}$ devices at the temperature range between $400^{\circ} \mathrm{C}$ and $500^{\circ} \mathrm{C}$ at $20 \mathrm{kHz}$.

Table 1. Sensitivities of $\mathrm{SmMeO}_{3}(\mathrm{Me}=\mathrm{Cr}, \mathrm{Mn}, \mathrm{Fe}, \mathrm{Co})$ and $\mathrm{LaFeO}_{3}$ devices to $5 \mathrm{ppm} \mathrm{C}_{2} \mathrm{H}_{2}$ and 50 ppm $\mathrm{C}_{2} \mathrm{H}_{4}$ at $400^{\circ} \mathrm{C}$ $500^{\circ} \mathrm{C}$ at $20 \mathrm{kHz}$.

\begin{tabular}{cccccccccccc}
\hline & $\mathrm{SmCrO}_{3}$ & $\mathrm{SmMnO}_{3}$ & $\mathrm{SmFeO}_{3}$ & $\mathrm{SmCoO}_{3}$ & $\mathrm{LaFeO}_{3}$ \\
\hline $\mathrm{Temp}$ & $\mathrm{C}_{2} \mathrm{H}_{2}$ & $\mathrm{C}_{2} \mathrm{H}_{4}$ & $\mathrm{C}_{2} \mathrm{H}_{2}$ & $\mathrm{C}_{2} \mathrm{H}_{4}$ & $\mathrm{C}_{2} \mathrm{H}_{2}$ & $\mathrm{C}_{2} \mathrm{H}_{4}$ & $\mathrm{C}_{2} \mathrm{H}_{2}$ & $\mathrm{C}_{2} \mathrm{H}_{4}$ & $\mathrm{C}_{2} \mathrm{H}_{2}$ & $\mathrm{C}_{2} \mathrm{H}_{4}$ \\
$400^{\circ} \mathrm{C}$ & 0 & 0 & 0.14 & 0 & 1.63 & -2.49 & 0 & 0 & 9.37 & 4.55 \\
$450^{\circ} \mathrm{C}$ & 0 & 0 & 0 & 0 & 6.15 & -0.981 & 0 & 0 & 7.62 & 4.69 \\
$500^{\circ} \mathrm{C}$ & 0 & 0 & 0 & 0 & 2.28 & 0 & 0 & 0 & 8.95 & 7.20 \\
\hline
\end{tabular}

${ }^{*}$ Gas concentration of $\mathrm{C}_{2} \mathrm{H}_{2}$ and $\mathrm{C}_{2} \mathrm{H}_{4}$ is $5 \mathrm{ppm}$ and $50 \mathrm{ppm}$, respectively. ${ }^{* *}$ Sensitivity $S_{\mathrm{R}}[\%]=\frac{R_{\mathrm{gas}}-R_{\mathrm{air}}}{R_{\mathrm{air}}} \times 100$. 
devices seldom showed apparent response to low concentration of $\mathrm{C}_{2} \mathrm{H}_{2}$ at the operating temperatures. One of the results would be expressed that surface-controlled gas sensor based oxide semiconductor is to be high conductivity by increasing working temperature. In details, the sensitivities were decreased because the change of surface conductivity with chemical reaction on oxide surface is relatively small for high bulk conductivity even if the oxide device is reacted to same $\mathrm{C}_{2} \mathrm{H}_{2}$ concentration.

For investigating the electrical properties of the prepared oxide thin-films, the conductivities was determined from Arrhenius equation in air at the temperature range between $200^{\circ} \mathrm{C}$ and $500^{\circ} \mathrm{C}$ in the frequency range from $50 \mathrm{~Hz}$ to $5 \mathrm{MHz}$ with applied voltage of $0.5 \mathrm{~V}$ by $\mathrm{AC}$ impedance method as shown in Figure 10. The conductivities $\sigma\left[\mathrm{S} \cdot \mathrm{cm}^{-1}\right]$ of all thin-films were calculated from their real part impedance $\left(Z^{\prime}\right)$ corresponding to the minimum of their imaginary part $\left(Z^{\prime \prime}\right)$ as shown in Figure 6.

The prepared thin-films represented an increased conductivity with increasing operating temperature, which has a typical semiconductor behavior. Although the $\mathrm{SmCrO}_{3}$ and $\mathrm{SmFeO}_{3}$ thin-films seldom showed low conductivity below $300^{\circ} \mathrm{C}$, the $\mathrm{SmMnO}_{3}$ and $\mathrm{SmCoO}_{3}$ thin-films showed still high conductivity below $300^{\circ} \mathrm{C}$. And also, large difference of the conductivities between $\mathrm{SmFeO}_{3}$ and $\mathrm{SmCoO}_{3}$ over the operating temperature range. Additionally, the activation energies of the films exhibited smaller than 1 except for the $\mathrm{SmFeO}_{3}$. Consequently, the $\mathrm{SmMnO}_{3}$ and $\mathrm{SmCoO}_{3}$ with a high conductivity and low activation energy would make it cause to react with a detection gas on their quite surface. As the variant condition of film formation and film thickness, the results showed a similar leaning with the La-based

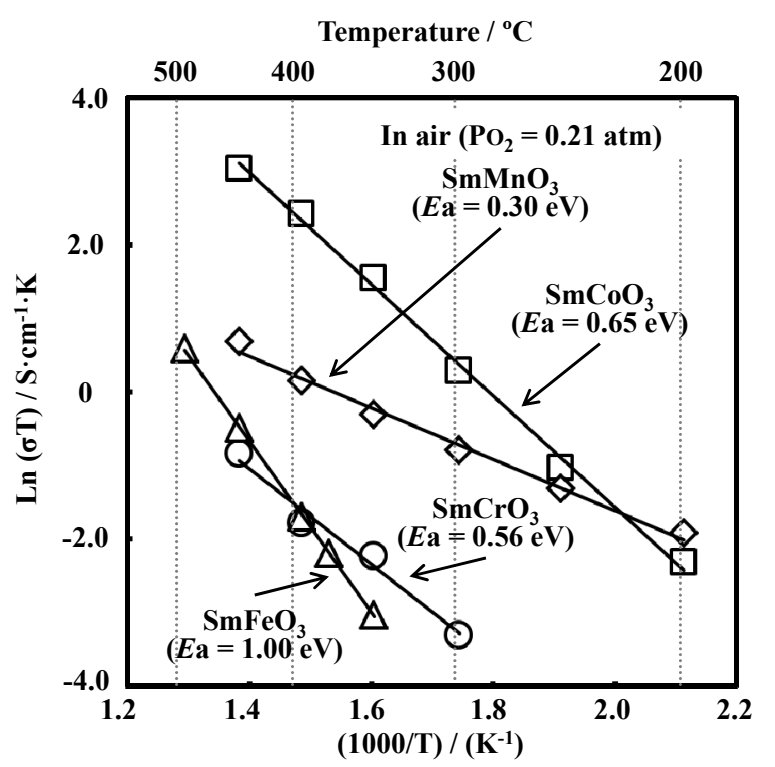

Figure 10. Arrhenius plots and activation energies of Sm$\mathrm{MeO}_{3}(\mathrm{Me}=\mathrm{Cr}, \mathrm{Mn}, \mathrm{Fe}, \mathrm{Co})$ and $\mathrm{LaFeO}_{3}$ thin-films.

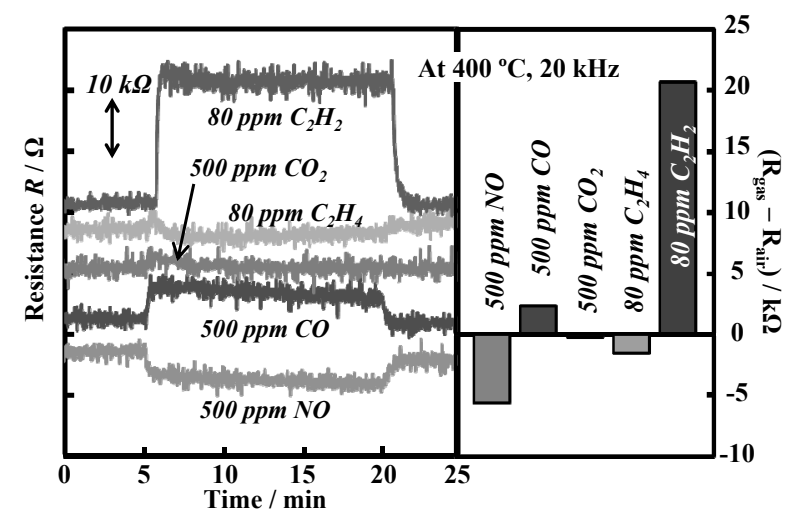

Figure 11. Selectivity of the $\mathrm{SmFeO}_{3}$ thin-film device to various gases, such as $80 \mathrm{ppm} \mathrm{C}_{2} \mathrm{H}_{2}, 80 \mathrm{ppm} \mathrm{C}_{2} \mathrm{H}_{4}, 500 \mathrm{ppm}$ $\mathrm{CO}_{2}, 500 \mathrm{ppm} \mathrm{CO}$ and $500 \mathrm{ppm}$ NO at $400^{\circ} \mathrm{C}, 20 \mathrm{kHz}$.

perovskite thin-film reported Ngamou et al. and occurred the charge transfer $\left(\mathrm{Me}^{4+} \leftrightarrow \mathrm{Me}^{3+}\right)$ via the $\mathrm{Me}-\mathrm{O}-\mathrm{Me}$ bonds [30].

Figure 11 shows the selectivity of $\mathrm{SmFeO}_{3}$ thin-film device to interference gases such as $80 \mathrm{ppm}_{2} \mathrm{H}_{4}, 500$ ppm $\mathrm{CO}$ and $500 \mathrm{ppm} \mathrm{CO}_{2}$ at $20 \mathrm{kHz}$ at $400^{\circ} \mathrm{C}$. The $\mathrm{SmFeO}_{3}$-based device showed little response to $\mathrm{C}_{2} \mathrm{H}_{4}$, $\mathrm{CO}$ and $\mathrm{CO}_{2}$, although this device showed good response to $\mathrm{C}_{2} \mathrm{H}_{2}$. This is the face that the obtained behavior arises from various mechanisms. In case of the device, one could express a general surface reaction as shown in Equation (2), where the pre-adsorbed reducing gas $R$ with a surface oxygen species $\left(\mathrm{O}^{2-}, \mathrm{O}_{2}^{-}\right.$or $\left.\mathrm{O}^{-}\right)$and releases electrons to the conduction band of the sensor $[27,29]$.

$$
R+x O_{\text {ads }}^{y} \rightarrow R O_{x}+|x y| e^{-}
$$

\section{Conclusion}

The perovskite-type oxide $\mathrm{SmMeO}_{3}(\mathrm{Me}=\mathrm{Cr}, \mathrm{Mn}, \mathrm{Fe}$, Co) thin-film sensors could be prepared by a polymer precursor method. The $\mathrm{SmFeO}_{3}$-based thin-film device showed good sensing characteristics to $\mathrm{C}_{2} \mathrm{H}_{2}$ between 2 and $80 \mathrm{ppm}$ at $400^{\circ} \mathrm{C}$ with $90 \%$ response time of ca. 15 sec. Moreover, the sensor device had relatively high sensitivity which showed increasing resistance response to $\mathrm{C}_{2} \mathrm{H}_{2}$.

\section{REFERENCES}

[1] D. B. Meadowcroft, "Low-Cost Oxygen Electrode Material," Nature, Vol. 226, No. 5248, 1970, pp. 847-848. doi: $10.1038 / 226847 \mathrm{a} 0$

[2] M. Yang, L. Huo, H. Zhao, S. Gao and Z. Rong, "Electrical Properties and Acetone-Sensing Characteristics of $\mathrm{LaNi}_{1-x} \mathrm{Ti}_{x} \mathrm{O}_{3}$ Perovskite System Prepared by Amorphous Citrate Decomposition," Sensors and Actuators B: Chemical, Vol. 143, No. 1, 2009, pp. 111-118. doi:10.1016/j.snb.2009.09.003 
[3] L. Zhang, H. Qin, P. Song, J. Hu and M. Jiang, "Electric Properties and Acetone-Sensing Characteristics of $\mathrm{La}_{1-x} \mathrm{~Pb}_{x} \mathrm{FeO}_{3}$ Perovskite System," Materials Chemistry and Physics, Vol. 98, No. 2-3, 2006, pp. 358-362. doi:10.1016/j.matchemphys.2005.09.041

[4] E. L. Brosha, R. Mukundan, R. Lujan and F. H. Garzon, "Mixed Potential $\mathrm{NO}_{x}$ Sensors Using Thin Film Electrodes and Electrolytes for Stationary Reciprocating Engine Type Applications," Sensors and Actuators B: Chemical, Vol. 119, No. 2, 2006, pp. 398-408. doi:10.1016/j.snb.2005.12.044

[5] G. N. Chaudhari, S. V. Jagtap, N. N. Gedam, M. J. Pawar and V. S. Sangawar, "Sol-Gel Synthesized Semiconducting $\mathrm{LaCo}_{0.8} \mathrm{Fe}_{0.2} \mathrm{O}_{3}$-Based Powder for Thick Film $\mathrm{NH}_{3}$ Gas Sensor," Talanta, Vol. 78, No. 3, 2009, pp. 1136-1140. doi:10.1016/j.talanta.2009.01.030

[6] K. Sahner, D. Schönauer, R. Moos, M. Matam and M. L. Post, "Effect of Electrodes and Zeolite Cover Layer on Hydrocarbon Sensing with $p$-Type Perovskite $\mathrm{SrTi}_{0.8} \mathrm{Fe}_{0.2} \mathrm{O}_{3-\delta}$ Thick and Thin Films," Journal of Materials Science, Vol. 41, No. 18, 2006, pp. 5828-5835. doi:10.1007/s10853-006-0299-x

[7] E. Delgado and C. R. Michel, " $\mathrm{CO}_{2}$ and $\mathrm{O}_{2}$ Sensing Behavior of Nanostructured Barium-Doped $\mathrm{SmCoO}_{3}$, , Materials Letters, Vol. 60, No. 13-14, 2006, pp. 1613-1616. doi:10.1016/j.matlet.2005.11.080

[8] Y. Shimizu and N. Yamashita, "Solid Electrolyte $\mathrm{CO}_{2}$ Sensor Using NASICON and Perovskite-Type Oxide Electrode," Sensors Actuators B: Chemical, Vol. 64, No. 1-3, 2000, pp. 102-106. doi:10.1016/S0925-4005(99)00491-8

[9] Y. L. Chai, D. T. Ray, G. J. Chen and Y. H. Chang, "Synthesis $\mathrm{La}_{0.8} \mathrm{Sr}_{0.2} \mathrm{Co}_{0.5} \mathrm{Ni}_{0.5} \mathrm{O}_{3-\delta}$ Thin Films for High Sensitivity CO Sensing Material Using the Pechini Process," Journal of Alloys and Compounds, Vol. 333, No. 1-2, 2002, pp. 147-153. doi:10.1016/S0925-8388(01)01688-7

[10] L. Malavasi, C. Tealdi, A. Montenero, J. M. Tulliani, P. Moggi, M. Guglielmi, G. Flor, A. Lorenzi, A. Martucci, L. Montanaro and G. Chiodelli, "Materials Development for CO-Detection with Improved Selectivity through Catalytic Activation," Sensors Actuators B: Chemical, Vol. 118, No. 1-2, 2006, pp. 121-128. doi:10.1016/j.snb.2006.04.008

[11] Y. Shimizu, A. Ishikawa, K. Iseki and S. Takase, "Perovskite-Type Oxide-Based Electrode: A New Sensor for Hydrogen-Phosphate Ion," Journal of the Eletrochemical Society, Vol. 147, No. 10, 2000, pp. 3931-3934. doi:10.1149/1.1393998

[12] H. M. Zhang, Y. Shimizu, Y. Teraoka, N. Miura and N. Yamazoe, "Oxygen Sorption and Catalytic Properties of $\mathrm{La}_{1-x} \mathrm{Sr}_{x} \mathrm{Co}_{1-y} \mathrm{Fe}_{y} \mathrm{O}_{3}$ Perovskite-Type Oxides," Journal of Catalysis, Vol. 121, No. 2, 1990, pp. 432-440. doi:10.1016/0021-9517(90)90251-E

[13] H. Aono, E. Traversa, M. Sakamoto and Y. Sadaoka, "Crystallographic Characterization and $\mathrm{NO}_{2}$ Gas Sensing Property of $\mathrm{LnFeO}_{3}$ Prepared by Thermal Decomposition of Ln-Fe Hexacyanocomplexes, $\operatorname{Ln}\left[\mathrm{Fe}(\mathrm{CN})_{6}\right] \cdot n \mathrm{H}_{2} \mathrm{O}, \mathrm{Ln}=$ La, Nd, Sm, Gd, and Dy," Sensors Actuators B: Chemical, Vol. 94, No. 2, 2003, pp. 132-139. doi:10.1016/S0925-4005(03)00328-9

[14] M. C. Carotta, G. Martinelli, Y. Sadaoka, P. Nunziante and
E. Traversa, "Gas-Sensitive Electrical Properties of Perovskite-Type $\mathrm{SmFeO}_{3}$ Thick Films," Sensors Actuators B: Chemical, Vol. 48, No. 1-3, 1998, pp. 270-276. doi:10.1016/S0925-4005(98)00011-2

[15] M. Tomoda, S. Okano, Y. Itagaki, H. Aono and Y. Sadaoka, "Air Quality Prediction by Using Semiconducting Gas Sensor with Newly Fabricated $\mathrm{SmFeO}_{3}$ Film," Sensors Actuators B: Chemical, Vol. 97, No. 2-3, 2004, pp. 190-197. doi:10.1016/j.snb.2003.08.013

[16] M. Zhao, H. Peng, S. Fang and J. Hu, "Microstructure, Electrical and Ethanol-Sensing Properties of PerovskiteType $\mathrm{SmFe}_{0.7} \mathrm{Co}_{0.3} \mathrm{O}_{3}$," Sensors Actuators B: Chemical, Vol. 130, No. 2, 2008, pp. 609-613. doi:10.1016/j.snb.2007.10.017

[17] C. M. Chiu and Y. H. Chang, "The Influence of Microstructure and Deposition Methods on CO Gas Sensing Properties of $\mathrm{La}_{0.8} \mathrm{Sr}_{0.2} \mathrm{Co}_{1-x} \mathrm{Ni}_{x} \mathrm{O}_{3-\delta}$ Perovskite Films," Sensors Actuators B: Chemical, Vol. 54, No. 3, 1999, pp. 236242. doi:10.1016/S0925-4005(99)00117-3

[18] M. J. Montenegro, T. Lippert, S. Müller, A. Weidenkaff, P. R. Willmott and A. Wokaun, "Pulsed Laser Deposition of Electrochemically Active Perovskite Films," Applied Surface Science, Vol. 197-198, 2002, pp. 505-511. doi:10.1016/S0169-4332(02)00326-4

[19] T. Kumagai, H. Yokota, K. Kawaguchi, W. Kondo and S. Mizuta, "Preparation of Superconducting $\mathrm{YBa}_{2} \mathrm{Cu}_{3} \mathrm{O}_{7-\delta}$ Thin Films by the Dipping-Pyrolysis Process Using Organic Acid Salts," Chemistry Letters, Vol. 16, No. 8, 1987, pp. 1645-1646. doi:10.1246/cl.1987.1645

[20] H. J. Hwang and M. Awano, "Preparation of $\mathrm{LaCoO}_{3}$ Catalytic Thin Film by the Sol-Gel Process and Its NO Decomposition Characteristics," Journal of the European Ceramic Society, Vol. 21, No. 10-11, 2001, pp. 2103-2107. doi:10.1016/S0955-2219(01)00181-9

[21] K. Tsuchida, S. Takase and Y. Shimizu, "Sol-Gel Synthesis of Perovskite-Type Oxide Thin-Film with Metal Organic-Acid and Its Application to Amperometric Hydrogen-Phosphate Ion Sensor," Sensors and Materials, Vol. 16, No. 3, 2004, pp. 171-180.

[22] Y. Pimtong-Ngam, S. Jiemsirilers and S. Supothina, "Preparation of Tungsten Oxide-Tin Oxide Nanocomposites and Their Ethylene Sensing Characteristics," Sensors and Actuators A: Physical, Vol. 139, No. 1-2, 2007, pp. 7-11. doi:10.1016/j.sna.2006.10.032

[23] L. R. Jordan and P. C. Hauser, "Electrochemical Sensor for Acetylene," Analytical Chemistry, Vol. 69, No. 14, 1997, pp. 2669-2672. doi:10.1021/ac9700585

[24] Q. Qi, T. Zhang, X. Zheng, H. Fan, L. Liu, R. Wang and Y. Zeng, "Electrical Response of $\mathrm{Sm}_{2} \mathrm{O}_{3}$-Doped $\mathrm{SnO}_{2}$ to $\mathrm{C}_{2} \mathrm{H}_{2}$ and Effect of Humidity Interference," Sensors Actuators B: Chemical, Vol. 134, No. 1, 2008, pp. 36-42. doi:10.1016/j.snb.2008.04.011

[25] S. T. Marshall, D. K. Schwartz and J. W. Medlin, "Selective Acetylene Detection through Surface Modification of Metal-Insulator-Semiconductor Sensors with Alkanethiolate Monolayers," Sensors Actuators B: Chemical, Vol. 136, No. 2, 2009, pp. 315-319. doi:10.1016/j.snb.2008.11.026

[26] Y. Shimizu and T. Murata, "Sol-Gel Synthesis of Perovskite-Type Lanthanum Manganite Thin Films and Fine 
Powders Using Metal Acetylacetonate and Poly(Vinyl Alcohol)," Journal of the American Ceramis Society, Vol. 80 , No. 10,1997 , pp. 2702-2704. doi:10.1111/j.1151-2916.1997.tb03178.x

[27] S. M. Bukhari and J. B. Giorgi, "Cobaot Doped $\mathrm{Sm}_{0.95} \mathrm{Ce}_{0.05} \mathrm{FeO}_{3-\delta}$ for Detection of Reducing Gases," Journal of the Electrochemical Society, Vol. 158, No. 6, 2011, pp. J159-J164. doi:10.1149/1.3570674

[28] S. M. Bukhari and J. B. Giorgi, "Tuneability of $\mathrm{Sm}_{(1-x)} \mathrm{Ce}_{x} \mathrm{FeO}_{3 \pm \lambda}$ Perovskites: Thermal Stability and Electrical Conductivity," Solid State Ionics, Vol. 180, No. 2-3,
2009, pp. 198-204. doi:10.1016/j.ssi.2008.12.002

[29] S. Luo, G. Fu, H. Chen, Z. Liu and Q. Hong, "Gas-Sensing Properties and Complex Impedance Analysis of CeAdded $\mathrm{WO}_{3}$ Nanoparticles to VOC Gases," Solid-State Electronics, Vol. 51, No. 6, 2007, pp. 913-919. doi:10.1016/j.sse.2007.04.010

[30] P. H. T. Ngamou and N. Bahlawane, "Chemical Vapor Deposition and Electric Characterization of Perovskite Oxides $\mathrm{LaMO}_{3}(M=\mathrm{Co}, \mathrm{Fe}, \mathrm{Cr}$ and $\mathrm{Mn})$ Thin Films," Journal of Solid State Chemistry, Vol. 182, No. 4, 2009, pp. 849-854. doi:10.1016/j.jssc.2008.12.017 